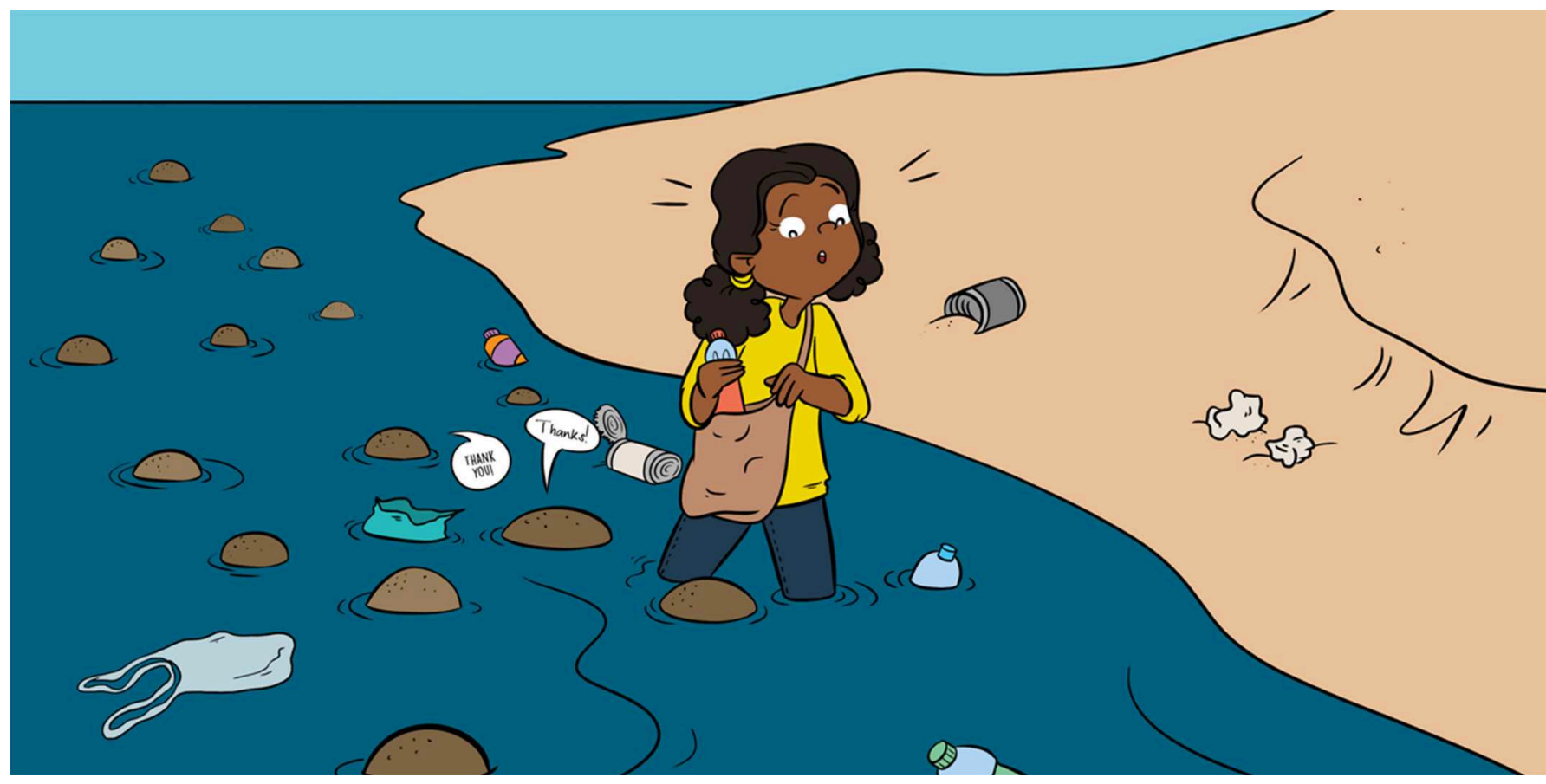

\title{
MICROBIALITES: WHAT ON EARTH?
}

Alfredo Yanez-Montalvo ${ }^{1,2}$, Bernardo Águila ${ }^{1}$, Elizabeth S. Gómez-Acata ${ }^{1}$, Yislem Beltrán ${ }^{3}$, Patricia M. Valdespino-Castillo ${ }^{4}$, Carla M. Centeno ${ }^{1}$ and Luisa I. Falcón ${ }^{1^{*}}$

${ }^{1}$ Instituto de Ecología, Universidad Nacional Autónoma de México, Mérida, Mexico

${ }^{2}$ El Colegio de la Frontera Sur, Chetumal, Mexico

3 Instituto de Ciencias del Mar y Limnología, Universidad Nacional Autónoma de México, Puerto Morelos, Mexico

${ }^{4}$ Lawrence Berkeley National Laboratory, Berkeley, CA, United States

\section{YOUNG REVIEWERS:}

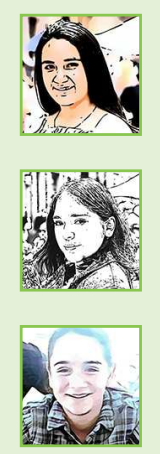

DANA

AGE: 14

MARÍA

JOSE

AGE: 14

MARIANA

AGE: 15
Microbialites are rock-like underwater structures that look like reefs but are made entirely of millions of microbes. These structures are very ancient and can be found in different environments on every continent on Earth. Mexico has many microbialite reefs, in desert valleys, crater-lakes, and coastal lagoons. Science helps us to understand the microbes that build microbialites, to know whether the same kinds of microbes make up microbialites in different regions of the world, and to figure out how the microbes organize into microbialites. Many things are damaging microbialites in Mexico, including poorly planned development, pollution from lack of sewage treatment, too much water usage, and the fertilizers used for agriculture. Policies that regulate development are urgently needed to help save these diverse and ancient microbial reefs. 
MICROBIALITE

A rock-like structure made by millions of microbes that precipitate carbonate.

\section{MICROBE}

An organism that is seen under the microscope.

\section{STROMATOLITE}

Fossilized microbialites, and are the oldest fossils dated so far.

\section{CYANOBACTERIA}

A phylum of bacteria that can make photosynthesis.

EXOPOLYMERIC SUBSTANCES (EPS)

Mucous-like molecules released by microorganisms into their environment, which help the microbes remain close together and communicate with each other.

\section{WHAT ARE MICROBIALITES?}

Do you know what a microbialite is? Not many people do. This is because microbialites look like slimy underwater rocks, but they are actually reefs made up of microbes (simple, one-celled organisms). Microbialites are fascinating, because these rock-like structures are made by the interaction of millions of microbes that live in certain aquatic environments. The microbes facilitate the precipitation of minerals from the water, to form the microbialite structure [1]. Since microbialites are like rocks, they have remained on earth since extremely ancient times. Fossilized microbialites, known as stromatolites (from the Greek strõma, meaning bed or layer, and lithos, meaning rock), are the oldest evidence of life on Earth, dating back to 3.7 billion years ago [2].

Cyanobacteria are one type of microbe found in microbialites, and these bacteria do all kinds of important work. Cyanobacteria build shelters that protect the microbial community from dangerous things in the environment, including protecting them from drying out and from damage by the sun's UV rays. The shelters built by cyanobacteria trap and bind sediments and minerals, which help to grow the microbialites [3, 4]. Cyanobacteria are also involved in producing slimy substances called exopolymeric substances (EPS), which are like mucous. Exopolymeric substances help microbes to stay close to each other and allow the cells to communicate with each other [4]. Cyanobacteria also have pigments that interact with photons from the Sun, allowing them to perform photosynthesis, which leads to the incorporation of carbon from the atmosphere (in the form of $\mathrm{CO}_{2}$ ) into their cells. Cyanobacteria take up water and produce oxygen during photosynthesis. Since microbialites are so old, they probably participated in oxygenating the early Earth. Gently and slowly, bubble by bubble, microbialites produced oxygen, and by $\sim 2.4$ billion years ago, the chemistry of earth's atmosphere had changed enough to support the evolution of other life forms [5]. Cyanobacteria are one of the food sources for other kinds of microbes, helping many different kinds of microbes work together as a unit to form the microbialite community.

\section{WHERE DO MICROBIALITES LIVE?}

There are living microbialites in different aquatic environments all over the globe, including polar, temperate, and tropical locations. In Mexico, there are microbialite communities in different locations, including coastal lagoons, crater-lakes, and desert ponds (Figure 1).

\section{ARE ALL MICROBIALITES IN MEXICO THE SAME?}

In our study, we wanted to understand if microbialites from different locations in Mexico are similar or different, in terms of the microbes 
Figure 1

Microbialite reef locations in Mexico that were examined in our study: Cuatro Ciénegas basin in Northern México, crater-lake Alchichica in Central México, and Bacalar lagoon in the Yucatán Península.

\section{POLYMERASE}

CHAIN REACTION (PCR)

A laboratory technique for obtaining millions of copies of pieces of DNA, so that they can be more easily analyzed.

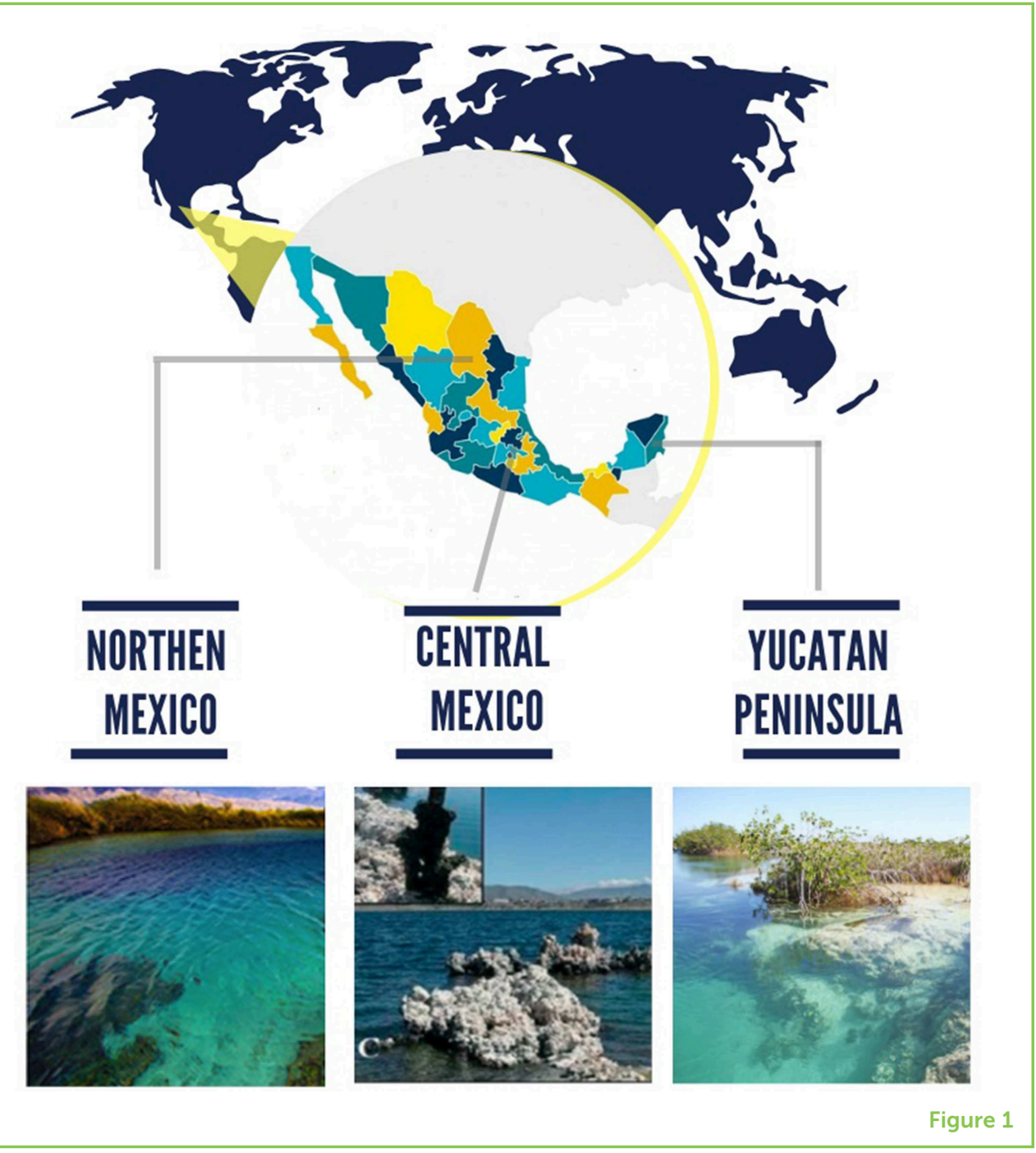

that make them up. To study this, we explored various sites using catamarans, kayaks, and boats. Once we identified microbialite reefs, we took small samples $(\sim 2 \mathrm{~g})$ of microbialites from the first few millimeters of their surface, using clean, microbe-free tools and containers. We stored these samples in coolers and then froze them when we got back to the laboratory. Later, we extracted the DNA from these microbialite samples, using different enzymes, soaps, and organic molecules. To study this DNA, we first amplified it using a technique known as polymerase chain reaction (PCR) and analyzed how similar or different the microbial DNA sequences were to each other.

By comparing certain regions of the microbial DNA, thousands of microbes can be identified from a pea-sized rocky sample!

We found that all the microbialite communities we studied had the same groups of microbes, just in slightly different proportions (Figure 2) [6]. The main microbes in microbialites are Cyanobacteria (which we already discussed), Proteobacteria and Bacteroidetes 
Figure 2

Several different kinds of bacteria make up the microbialites found in various regions of Mexico. The types of bacteria are listed on the left, and the pie charts under the pictures of the microbialites show that microbialites from each location are made up of different proportions of these same types of bacteria.

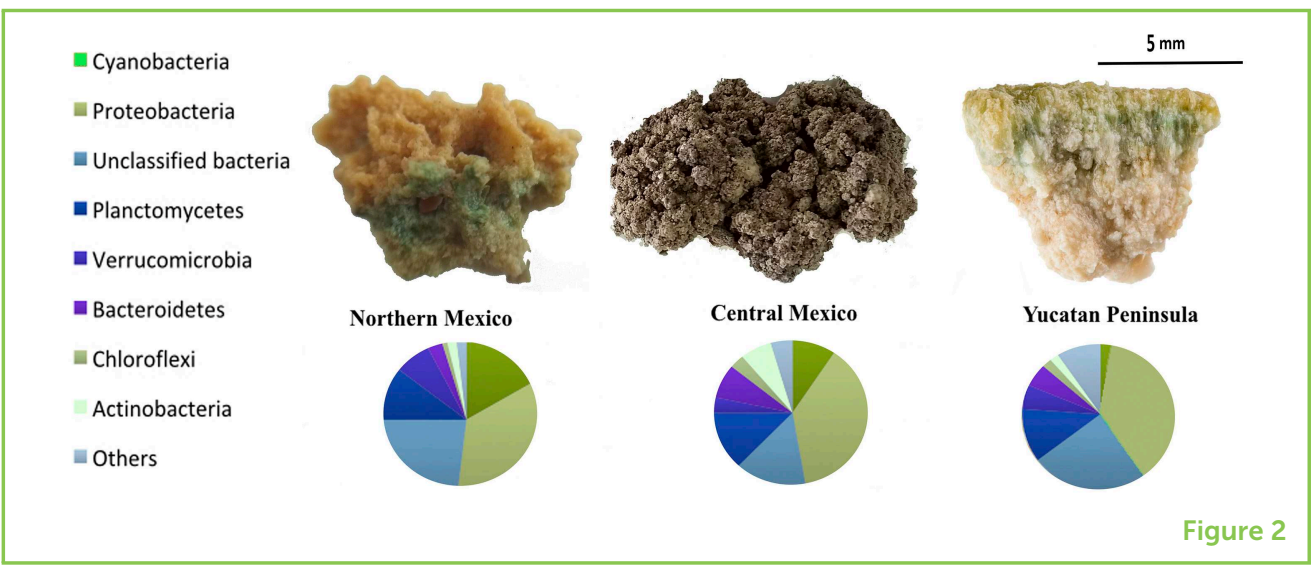

(which are very diverse and can digest many types of substrates, including carbon, nitrogen, and sulfur), Chloroflexi (which can do a type of photosynthesis that does not produce oxygen, but instead produces a substance called sulfide), and Archaea (which can produce and eat methane) (Figure 3).

Proteobacteria are the most diverse bacteria in microbialites, making up $30-40 \%$ of the total diversity in these structures, followed by a group of bacteria that we know very little about and are called unclassified bacteria, which make $\sim 20 \%$ of the bacteria in microbialites. Other bacteria, including Bacteroidetes, Plactomycetes, Verrucomicrobia, Chloroflexi, and Cyanobacteria comprise the remaining diversity (Figure 2). The microbes in microbialites have been interacting amongst themselves and with the environment for many millions of years, and have helped transform the Earth, making our life on this planet possible through the production of oxygen and other important processes. Microbial communities like the ones that form microbialites help the Earth to function as a unit.

\section{ARE MICROBIALITES IN MEXICO DOING WELL?}

Since microbialites are self-sufficient, they only need clean water, sunlight, and gases from the atmosphere to grow and develop. All the microbialites we have studied in Mexico live in places with clean and clear water, and we have found massive microbialite formations that have been dated to be $\sim 10,000$ years of age [7]. Some of the beautiful aquatic environments where microbialites have thrived for thousands of years have warm, clear, tropical waters. This is the case for a coastal lagoon called Bacalar in southern Mexico, which has attracted loads of tourists. But a problem arises when there is no infrastructure to treat the sewage from the growing population, leading to pollution of the lagoon. Microbialites in Bacalar lagoon and in other areas of Mexico are being threatened by human activities. In northern Mexico, the microbialites that thrive in the 
Figure 3

Many microbes build microbialites. They do photosynthesis, and capture $\mathrm{CO}_{2}$,

producing oxygen and are active in the nitrogen, sulfur and methane cycles.

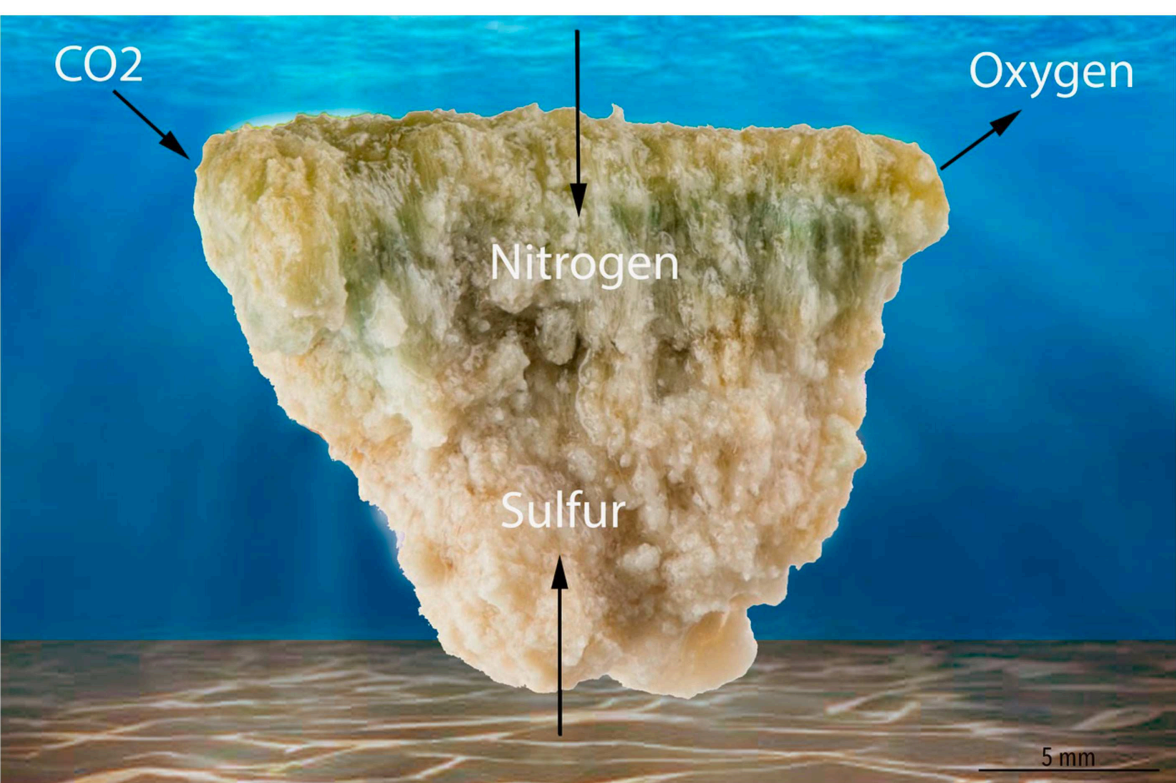

Figure 3

Cuatro Cienegas valley, which has many ponds in the middle of a desert, are at risk because too much water is being removed from the ponds for agriculture. In central Mexico, microbialites that live in crater-lakes are also at risk, due to both pollution and too much water usage.

Humans are the main problem for the world's biodiversity, but we are also the solution. Microbialites are part of Earth's history and it is wonderful that we can observe these ancient communities today! We have the responsibility to be educated about our environment and to make intelligent choices. Let us use efficient water treatment and technology to save microbialites and other aquatic life! Before going on a holiday, read about the places you will visit and learn about the plants, animals, and bacteria that live there, so that you can enjoy their company without harming them or their environment.

\section{AUTHOR CONTRIBUTIONS}

The authors contributed equally to writing this paper.

\section{ORIGINAL SOURCE ARTICLE}

Valdespino-Castillo, P. M., Hu, P., Merino-Ibarra, M., López-Gómez, L. M., Cerqueda-García, D., González-De Zayas, R., et al. 2018. Exploring biogeochemistry and microbial diversity of extant microbialites in Mexico and Cuba. Front. Microbiol. 9:510. doi: 10.3389/fmicb. 2018.00510 


\section{REFERENCES}

1. Reid, R. P., Visscher, P. T., Decho, A. W., Stolz, J. F., Bebout, B. M., Dupraz, C., et al. 2000. The role of microbes in accretion, lamination and early lithification of modern marine stromatolites. Nature 406:989-92. doi: 10.1038/35023158

2. Nutman, A. P., Bennett, V. C., Friend, C. R., Van Kranendonk, M. J., and Chivas, A. R. 2016. Rapid emergence of life shown by discovery of 3,700-million-year-old microbial structures. Nature 537:535-8. doi: 10.1038/nature19355

3. Watnick, P., and Kolter, R. 2000. Biofilm, city of microbes. J. Bacteriol. 182:2675-9. doi: 10.1128/JB.182.10.2675-2679.2000

4. Flemming, H. C., and Wingender, J. 2010. The biofilm matrix. Nat. Rev. Microbiol. 8:623-33. doi: 10.1038/nrmicro2415

5. Johnston, D. T., Wolfe-Simon, F., Pearson, A., and Knoll, A. H. 2009. Anoxygenic photosynthesis modulated proterozoic oxygen and sustained Earth's middle age. Proc. Natl. Acad. Sci. U.S.A. 106:16925-9. doi: 10.1073/pnas.0909248106

6. Valdespino-Castillo, P. M., Hu, P., Merino-Ibarra, M., López-Gómez, L. M., Cerqueda-García, D., González-De Zayas, R., et al. 2018. Exploring biogeochemistry and microbial diversity of extant microbialites in Mexico and Cuba. Front. Microbiol. 9:510. doi: 10.3389/fmicb.2018.00510

7. Gischler, E., Glbson, M. E., and Oschmann, W. 2008. Giant holocene freshwater microbialites, laguna bacalar, quintana roo, Mexico. Sedimentology 55:1293-309. doi: 10.1111/j.1365-3091.2007.00946.x

SUBMITTED: 05 December 2018; ACCEPTED: 15 August 2019; PUBLISHED ONLINE: 13 September 2019.

EDITED BY: Francisco Barona-Gomez, National Laboratory of Genomics for Biodiversity, Center for Research and Advanced Studies of the National Polytechnic Institute, Mexico

CITATION: Yanez-Montalvo A, Águila B, Gómez-Acata ES, Beltrán Y, Valdespino-Castillo PM, Centeno CM and Falcón LI (2019) Microbialites: What on Earth? Front. Young Minds 7:112. doi: 10.3389/frym.2019.00112

CONFLICT OF INTEREST STATEMENT: The authors declare that the research was conducted in the absence of any commercial or financial relationships that could be construed as a potential conflict of interest.

COPYRIGHT @ 2019 Yanez-Montalvo, Águila, Gómez-Acata, Beltrán, Valdespino-Castillo, Centeno and Falcón. This is an open-access article distributed under the terms of the Creative Commons Attribution License (CC BY). The use, distribution or reproduction in other forums is permitted, provided the original author(s) and the copyright owner(s) are credited and that the original publication in this journal is cited, in accordance with accepted academic practice. No use, distribution or reproduction is permitted which does not comply with these terms. 

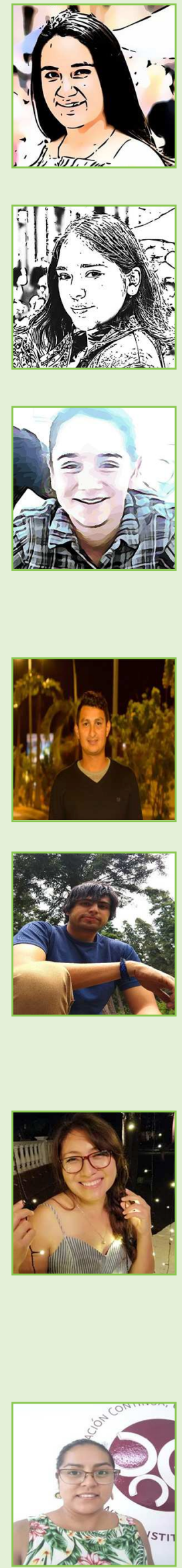

\section{YOUNG REVIEWERS}

\section{DANA, AGE: 14}

My name is Dana. I am 14 years old and I live in Guanajuato, Mexico. I have been dancing ballet and jazz since I was 2 years. I love science, specially astronomy. I would like to study it in the future. I also would like to be an engineer or a lawyer.

\section{MARÍA JOSE, AGE: 14}

My name is María Jose, my friends call me Majo. I am 14 years old, I live in Guanajuato, Mexico. I like ballet, I have been practice it since I was 3 years old. I like science and I want to be a doctor.

\section{MARIANA, AGE: 15}

My Name is Mariana, I am 15 years old and I live in Guanajuato, Mexico. My favorite sport is squash, I have been playing it since I was 6 years old. My favorite subjects are History and Chemistry. In the future I would like to become a Scientist.

\section{AUTHORS}

\section{ALFREDO YANEZ-MONTALVO}

I am Ph.D. student in Ecology and Sustainable Development. I am passionate about the study of microbial ecology and the understanding of how this microbial diversity is affected by natural and human activities. I love poetry, sports, and Bacalar lagoon. Every day we can learn from people and nature.

\section{BERNARDO ÁGUILA SALGADO}

I am Ph.D. student, a curious and geeky person. I am in love with arts, technology and popular science, specially natural science topics, such as biology, geology, astronomy, and environmental sciences. I am very interested in microorganisms that have an important role in the function of ecosystems. I am also aware of the environmental problems we may face in a future and I would like to contribute in some way to the solution.

\section{ELIZABETH S. GÓMEZ-ACATA}

I am a microbiologist working as a post-doctoral researcher at Universidad Nacional Autonoma de Mexico. I am fascinated with microbial life. I love studying microorganisms in any environment because they are very important for life on the planet. I also like to investigate biotechnological applications of microorganisms for taking care of the environment. I enjoy looking at them on the microscope and studying them with molecular techniques. In my free time, I enjoy traveling, photography, and cross-stitch embroidery. I love my family and enjoy life.

\section{YISLEM BELTRÁN}

I am a post-doctoral fellow at UNAM in Mexico. I am interested in microbial diversity and to understand patterns that characterize the presence of bacterial communities in different environments, as well as their response to environmental changes. What I like about this research is that I have been able to travel and know 

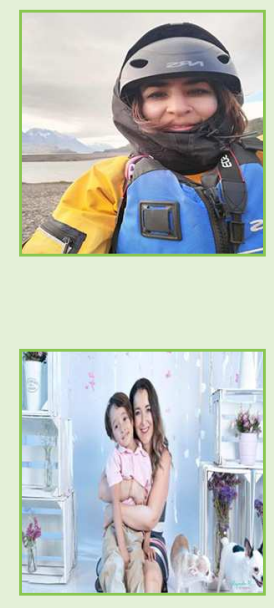

beautiful places, but also, I can combine field and molecular work and learn about computer sciences.

\section{PATRICIA M. VALDESPINO-CASTILLO}

I am a Ph.D. in Marine Science and Limnology. I am fascinated by the microbes of the environment, they are the most ancient and the most powerful mini-machines of life. Science, music and outdoor activities are very important for me; therefore I want to try any possible combination of these. I love being illuminated by curious young minds.

\section{CARLA M. CENTENO}

Since I was a little girl I wanted to be a biologist, because I was interested in understanding natural phenomena. When I learned about microorganisms I was fascinated by their shape, their tricky simplicity, the time they spend on our planet (millions of years) and their diversity. I love laboratory work and I really enjoy teaching. I have two small children to whom I teach respect and love toward all life forms.

\section{LUISA I. FALCÓN}

I am a microbial ecologist at UNAM in Mexico, fascinated with the diversity of bacteria and archaea in the environment. I love how microbes interact with each other to complement their metabolic capabilities, allowing for communities and ecosystems to exist. *falconaecologia.unam.mx 